\title{
COMMUNITY FORESTRY IN MISSOURI, U.S.: ATTITUDES AND KNOWLEDGE OF LOCAL OFFICIALS
}

\author{
by Thomas Treiman' and Justine Gartner ${ }^{2}$
}

\begin{abstract}
A survey was employed to help understand the knowledge, motivation, and behavior of those responsible for tree care in 602 Missouri, U.S., communities. Our goal was to characterize the local agencies charged with managing urban trees, their budgets and personnel, and to determine which issues local officials responsible for managing publicly owned trees found to be most pressing. This information is used to evaluate the state's community forestry program, which is designed to coordinate and facilitate the efforts made by many jurisdictions and entities that own and affect community forests. Survey findings indicate that most communities lack basic information on tree care and do not employ anyone specifically to care for the community's trees. Responsibility for tree care can be in any number of departments (or none). Agencies working with communities will need to target basic training and information. Information on how to diversify funding and secure more stable sources of income will prove valuable because many communities budget zero dollars for tree care. Cost-share dollars should also be targeted with an emphasis on increasing participation among smaller communities. Interest in tree preservation during development is high in most communities, underlining the need to provide information on development principles that preserve or maximize greenspace.
\end{abstract}

Key Words. Urban and community forestry; tree program; survey research; Missouri.

Like similar agencies in many states, the Missouri Department of Conservation (MDC) administers a community forestry program that is designed to advise, coordinate, and facilitate the efforts made by many jurisdictions and entities that own and affect community forests. MDC urban foresters help communities, local governments, and individuals manage the trees that make up community or urban forests. Managing these resources improves the environmental, social, and economic well being of each community and ultimately the state of Missouri (see, for example, Akbari 2002 for more on the environmental benefits of shade trees, Dwyer et al. 1992 for more on economic benefits, and Dwyer et al. 1994 for more on social effects).

The 2000 census found 763 incorporated cities and 209 villages in Missouri, with a total population of 5,595,211. Nearly as many Missourians live in communities with fewer than 10,000 people as do in those with more than 150,000 (Table 1). For this reason, and because MDC is charged with serving the whole state, much of our analysis will focus on those smaller communities.

Trained professionals responsible for tree care are what we will call in this paper "urban foresters." MDC employs nine individuals who are specifically titled urban foresters. These nine are located in Missouri's largest and/or fastestgrowing communities. In addition, community forestry assistance is provided by all other MDC foresters throughout the state. These foresters provide assistance to local, regional, and state governments; individuals; developers; the green industry; and anyone with an interest in managing community trees. Foresters advise on development of tree care programs, municipal tree ordinances and tree boards, and the location of new trees. Tree plans are provided for public property such as parks, schools, streets, and building grounds. MDC annually spends over $\$ 440,000$ in support of the community forestry program (in state funds) and another $\$ 250,000$ in personnel and operating costs (in federal funds). The majority of these funds support an annual community forestry cost-share program called Tree Resource Improvement and Maintenance II (TRIM II) (Missouri Department of Conservation 2003). These dollars do not include personnel costs.

Table 1. Distribution of community sizes in Missouri (Missouri Secretary of State 2003).

\begin{tabular}{lccc}
\hline Community size class & $\begin{array}{l}\text { Number of } \\
\text { communities }\end{array}$ & $\begin{array}{l}\text { Average } \\
\text { population }\end{array}$ & $\begin{array}{l}\text { Total } \\
\text { population }\end{array}$ \\
\hline Cities & 635 & $1,072.5$ & 681,062 \\
Less than 5,000 & 56 & $7,160.2$ & 400,971 \\
Between 5,001 and 10,000 & 37 & $13,522.0$ & 500,316 \\
Between 10,001 and 20,000 & 25 & $30,578.6$ & 764,466 \\
Between 20,001 and 50,000 & 7 & $72,064.0$ & 504,448 \\
Between 50,001 and 150,000 & 1 & $151,823.0$ & 151,823 \\
Between 150,001 and 250,000 & 2 & $394,729.0$ & 789,458 \\
More than 250,000 & & & \\
Villages & 208 & 294.1 & 61,178 \\
Less than 5,000 & 1 & $5,386.0$ & 5,386 \\
Between 5,001 and 10,000 & & & \\
\hline
\end{tabular}


To provide better and more targeted service to communities and local governments to help them manage their urban forest resource, state agencies need a better understanding of what that resource consists of and how it is currently managed.

MDC has conducted two urban tree surveys on plots in Missouri communities. The most recent survey was completed in 1999. The sample plots were first surveyed in 1989 in cooperation with the American Forestry Association and the USDA Forest Service as part of a nationwide survey of urban forests (Rocca 1992). The 1999 survey was one of the first follow-up surveys done by any state. A comparison of data shows significant changes in Missouri's community forests. Results show more trees but a decline in their condition. Missouri's urban forests are becoming more diverse (Gartner et al. 2002). The top six tree species constitute $37 \%$ of those surveyed in 1999 , as compared to 53\% found in 1989. The average value of a Missouri street tree increased by $\$ 642$ (in nominal terms), using the Council of Tree \& Landscape Appraisers' formulas (CTLA 1992). No trends appeared from the 1999 data correlating community size with tree condition, size, or density. Methodologically, comparisons across towns or across population size classes from the 1999 survey may be difficult because the same individual surveyors usually surveyed whole towns and all the towns in a region (Gartner et al. 2002). Other studies across the nation have also focused on the physical inventory of urban trees (Baker 1993). Nowak et al. (2001), for example, found that urban areas in the United States contain approximately 3.8 billion trees, with an average tree canopy cover of $27 \%$.

However, there have been little or no data that could be used to attribute changes in the state's urban forest due to changes in community forestry programs, community demographic, local urban tree management department operations or budgets, or local officials' attitudes. Allen's (1996) questionnaire of Missouri community forestry officials provides some insight into the attitudes and behaviors of those responsible for managing the urban forest resource. Johnston and Rushton (1999) surveyed local authorities in Britain. They found a wide range of structures (such as departments, divisions, etc.) responsible for community trees, but that giving one specialist responsibility for overall management was the most "consistent with urban forestry." Schroeder et al. (2003) focused on small communities in Illinois, finding that smaller communities often lack key components of a successful tree program. They note that assistance to large communities can be a cost-effective way of reaching "large and diverse segments of the population." Further, they stress that small communities may benefit more from aid on "basic tree management practices." Elmendorf et al. (2003) provided a valuable review of municipal urban forestry practices studies, noting which practices are most frequently adopted. Their study suggests that many aspects of basic tree management and tree benefits are not understood by community leaders. They recommend a "planned process of communication" for these ideas. The state of California has undertaken a series of surveys of community officials on urban and community forestry (Thompson and Ahern 2000). They found an increase in budgets over time (1992 to 1998), a tendency to align programs within the local parks and recreation departments, as well as increased (positive) use of standards on pruning and anti-topping, inventories, and tree ordinances.

To better understand community forestry officials' knowledge, motivation, and behavior, we used a selfadministered survey questionnaire directed to local forestry officials in 602 Missouri communities. Our goal was to characterize the local agencies charged with managing urban trees, budgets, and personnel levels, and to determine which urban forestry issues local forestry officials found to be most pressing.

\section{METHODS}

A mail survey was designed and tested that included questions on which community department was responsible for street tree management and size of budget, and what sources of funds were used. Questions were also included on department size and the educational background of its employees, as well as on equipment, local tree ordinances, and familiarity with potential sources of outside money and advice. There were also several sets of questions asking respondents to rank their attitudes toward certain community forestry issues, such as hazard trees, topping, urban sprawl, and adequacy of funding and tree maintenance and planting. Finally, a set of demographic questions was included (see Treiman and Gartner 2003). The mail survey was self-administered; that is, respondents received the survey in the mail, completed it at their own pace, and returned it when finished.

A list of community officials responsible for tree care from 602 Missouri communities was purchased from the Missouri Municipal League (Figure 1). The list included all communities that were members in 2001 and any others for which the Municipal League was able to collect information. The bulk of the surveys were mailed to mayors or city administrators. However, an effort was made to mail surveys to parks and recreation and public works directors if the Municipal League had that information. There were a total of 642 names on the final mailing list, because 40 communities had more than one official identified as responsible for tree care and maintenance. The mailings followed Dillman's (2000) methodology, using an initial mailing and then a follow-up to nonrespondents. The overall response rate for the mailing list was $60 \%(387 / 642)$. 


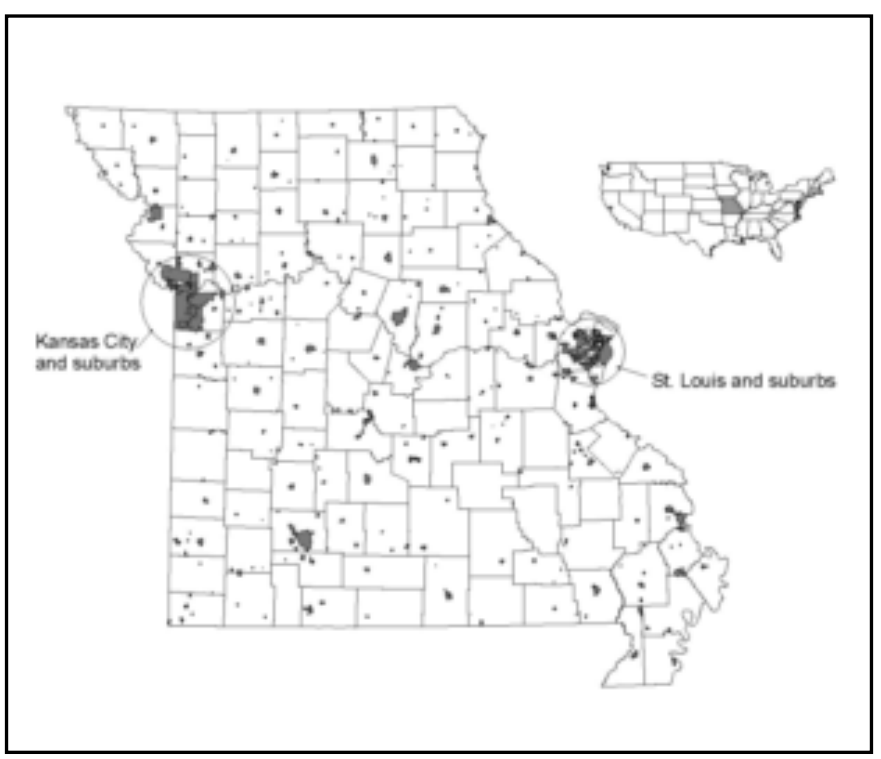

Figure 1. Locations of the 387 communities in Missouri, U.S., which returned responses to the self-administered mail survey on community forestry officials' attitudes, knowledge, and behaviors.

\section{RESULTS}

\section{Funding and Budget}

Most respondents reported that their communities receive the bulk of their funding for community/urban forestry activities through their general revenue stream (59\%); sales tax accounted for 14\% and "other" for $11 \%$ (Treiman and Gartner 2003). The National Arbor Day Foundation's Tree City USA program has established $\$ 2$ per capita as a minimum for communities to spend annually on tree care to achieve certification. Most Missouri communities are well below this benchmark, with $52 \%$ indicating that none of the city's total budget was designated for tree activities. Respondents recognize that their communities are lacking resources to manage and maintain publicly owned trees, with $54 \%$ of respondents disagreeing or strongly disagreeing with the statement that "My community provides enough resources to manage and maintain publicly owned trees."

\section{Responsibility for Tree Care and Maintenance}

Seventy-five percent of those surveyed indicated that their communities do not have a full-time person employed who spends the majority of his or her time performing treerelated activities. Sixty-two percent have one full-time employee who occasionally participates in tree care activities. Thirty percent do not have anyone who even occasionally participates in tree care activities. Only $7 \%$ have hired a fulltime degreed forester (a person with a B.S. in forestry, horticulture, or related subject). Communities with a population greater than 20,000 are more likely to employ degreed foresters. (This result has $P<.001$; Table 2.)

As community population rises, there is a very slight trend toward hiring one full-time employee (nondegreed) who spends the majority of his or her time performing treerelated activities. However, there are very few communities that employ more than one dedicated person. As community population tops 150,000 , communities tend to employ additional full-time forestry employees.

Respondents were asked to identify the department or departments responsible for tree care (instructed to check all that apply). The "maintenance department" was the most likely response, with $73 \%$ of the respondents identifying it. About $50 \%$ of parks and recreation departments and $42 \%$ of public works departments have tree care responsibilities.

\section{Ordinance and Written Tree Management Plan Communities with a written tree management plan ac- counted for $10 \%$ of all respondents, while $22 \%$ said they had a "comprehensive tree ordinance" on public property. Thirteen percent of respondents stated that their communi- ties have a "comprehensive tree ordinance that defines tree preservation requirements during development," yet $57 \%$ of respondents disagree or strongly disagree with the state- ment that their community is adequately addressing tree loss during development. Respondents in communities with a population under 5,000 and those with a population greater than 150,000 feel the most strongly that their community is not adequately addressing this issue. Those in communities with a population from 10,000 to 150,000}

Table 2. Cross-tabulation showing the relationship between community size and the number of employees with forestry degrees.

\begin{tabular}{|c|c|c|c|c|c|c|}
\hline \multirow[b]{2}{*}{ Community size } & \multicolumn{6}{|c|}{ Number of employees with forestry degrees } \\
\hline & None & 1 & 2 & 3 or more & Do not know & Total \\
\hline Under 5,000 & $267(69.5 \%)$ & $1(0.3 \%)$ & $0(0 \%)$ & $0(0 \%)$ & $2(0.5 \%)$ & $270(70.3 \%)$ \\
\hline 10,001 to 20,000 & $26(6.8 \%)$ & $4(1.0 \%)$ & $2(.05 \%)$ & $1(0.3 \%)$ & $1(.3 \%)$ & $34(8.9 \%)$ \\
\hline 20,000 to 50,000 & $10(2.6 \%)$ & $10(2.6 \%)$ & $3(0.8 \%)$ & $0(0 \%)$ & $0(0 \%)$ & $23(6.0 \%)$ \\
\hline 50,000 to 150,000 & $0(0 \%)$ & $5(1.3 \%)$ & $2(0.5 \%)$ & $0(0 \%)$ & $0(0 \%)$ & $7(1.8 \%)$ \\
\hline Total & $345(89.8 \%)$ & $26(6.8 \%)$ & $7(1.8 \%)$ & $3(0.8 \%)$ & $3(0.8 \%)$ & $384(100 \%)$ \\
\hline
\end{tabular}

Sample size $=384$, Chi square $=449.9(P<.0001, \mathrm{DF}=24)$. 
tend to be more neutral on this topic $(P<.05$; Table 3$)$. Respondents in communities that employee a degreed forester tend to be more neutral on this topic and feel less strongly that their community is not adequately addressing development $(P<.001)$.

Programs Used for Tree Projects in Communities The various cost-share programs sponsored by the MDC Community Forestry Program were utilized by many communities, with $28 \%$ of respondents indicating they had used one or more of the programs. Officials in $84 \%$ the communities surveyed with a population less then 5,000 indicated they had not used any cost-share program. A community that employs one full-time person to address tree care needs is much more likely to apply for cost-share $(P<.001$; Table 4$)$.

There is a strong positive correlation between communities being willing to budget for tree care activities and their participation in state cost-share programs $(P<.001)$. Also, there is a strong correlation between the existence of a public tree ordinance and the community's participation in one of the cost-share programs $(P<.001)$. Communities that use or apply for cost-share programs are more likely to have a tree preservation ordinance in place than those that do not, although this relationship is not as strong as the correlation between participation and a public ordinance $(P<.001)$. The St. Louis suburban communities utilize cost share programs more (19\%) than communities in the suburbs of Kansas City (4\%) $(P<.001$; Table 5$)$.

\section{Tree Condition and Maintenance}

Public officials in general feel that their community's trees are in good condition, with $71 \%$ expressing agreement or neutrality with the statement that "The publicly owned trees in my community are of good condition." Forty-one percent of respondents indicate they feel their community does not have enough public trees. This finding contrasts with results showing that communities typically do not have money budgeted for trees and tree care and interest in tree planting is not strong. Tree topping is not a primary concern for most communities, with $50 \%$ of respondents stating that they disagreed or strongly disagreed that tree topping was a problem.

Most respondents (64\%) rated removal of hazardous trees as very important, and 52\% feel that hazardous trees are a problem in their community. Respondents from communities that employ a forester would in general disagree or be neutral that hazard trees are a problem in their community. Communities without a forester in general disagree or strongly disagree that hazard trees are a problem.

\section{DISCUSSION \\ Methods, Respondent Selection and Contact, and Nonrespondent Bias}

Self-administered mail surveys are common and well accepted in the literature (Dillman 2000), but a survey with a $60 \%$ response rate may raise questions of nonrespondent bias. Although this project did not include a specific nonrespondent study, the two mailings do allow for some analysis. By comparing the answers of those who responded to the first mailing and those who responded to the second

Table 3. Cross-tabulation of community size and respondent agreement/disagreement with "My community is adequately addressing tree loss due to development."

\begin{tabular}{|c|c|c|c|c|c|c|}
\hline Community size & Strongly agree & Agree & Neutral & Disagree & Strongly disagree & Total \\
\hline Under 5,000 & $11(3.0 \%)$ & $16(4.4 \%)$ & $68(18.6 \%)$ & $65(17.8 \%)$ & $93(25.4 \%)$ & $253(69.3 \%)$ \\
\hline 5,001 to 10,000 & $3(0.8 \%)$ & $5(1.4 \%)$ & $16(4.4 \%)$ & $16(4.4 \%)$ & $5(1.4 \%)$ & $45(12.3 \%)$ \\
\hline 20,000 to 50,000 & $3(0.8 \%)$ & $4(1.1 \%)$ & $8(2.2 \%)$ & $4(1.1 \%)$ & $4(1.1 \%)$ & $23(6.3 \%)$ \\
\hline 50,000 to 150,000 & $1(0.3 \%)$ & $0(0 \%)$ & $2(0.6 \%)$ & $3(0.8 \%)$ & $1(0.3 \%)$ & $7(1.9 \%)$ \\
\hline 150,000 to 250,000 & $0(0 \%)$ & $0(0 \%)$ & $0(0 \%)$ & $0(0 \%)$ & $1(0.3 \%)$ & $1(0.3 \%)$ \\
\hline
\end{tabular}

Sample size $=366$, Chi square $=40.8(P=.02, \mathrm{DF}=24)$.

Table 4. Cross-tabulation of number of full-time employees and the use of/application for any state urban forestry cost-share program.

\begin{tabular}{|c|c|c|c|c|c|c|}
\hline \multirow[b]{2}{*}{ Cost-share participation } & \multicolumn{6}{|c|}{ Number of full-time employees } \\
\hline & $\overline{\text { None }}$ & 1 & 2 & 3 or more & Do not know & Total \\
\hline Do not use cost share & $223(59.6 \%)$ & $42(11.2 \%)$ & $1(0.3 \%)$ & $0(0 \%)$ & $1(0.3 \%)$ & $267(71.4 \%)$ \\
\hline Total & $280(74.9 \%)$ & $89(23.8 \%)$ & $3(0.8 \%)$ & $1(0.3 \%)$ & $1(0.3 \%)$ & $374(100 \%)$ \\
\hline
\end{tabular}

Sample size $=374$, Chi square $=39.9(P<.0001, \mathrm{DF}=4)$. 
Table 5. Cross-tabulation of community size/status and the use of/application for any state urban forestry cost-share program.

\begin{tabular}{llll}
\hline Community group & Do not use cost share & Use cost share & Total \\
\hline Under 5,000 & $207(53.5 \%)$ & $34(8.8 \%)$ & $241(62.3 \%)$ \\
5,001 to 10,000 & $17(4.4 \%)$ & $19(4.9 \%)$ & $36(9.3 \%)$ \\
10,001 to 20,000 & $11(2.8 \%)$ & $17(4.4 \%)$ & $28(7.2 \%)$ \\
20,001 to 50,000 & $5(1.3 \%)$ & $9(2.3 \%)$ & $14(3.6 \%)$ \\
50,001 to 150,000 & $0(0 \%)$ & $2(0.5 \%)$ & $2(0.5 \%)$ \\
150,001 or more & $0(0 \%)$ & $1(0.3 \%)$ & $1(0.3 \%)$ \\
St. Louis suburbs & $27(7.0 \%)$ & $21(5.4 \%)$ & $48(12.4 \%)$ \\
Kansas City suburbs & $11(2.8 \%)$ & $4(1.0 \%)$ & $15(3.9 \%)$ \\
St. Louis & $0(0 \%)$ & $1(0.3 \%)$ & $1(0.3 \%)$ \\
Kansas City & $0(0 \%)$ & $1(0.3 \%)$ & $1(0.3 \%)$ \\
Total & $\mathbf{2 7 8}(\mathbf{7 1 . 8 \% )}$ & $\mathbf{1 0 9}(\mathbf{2 8 . 2 \% )}$ & $\mathbf{3 8 7}(\mathbf{1 0 0} \%)$ \\
\hline
\end{tabular}

Sample size $=387$, Chi square $=76.5(P<.0001, \mathrm{DF}=9)$.

or later, we can test the hypothesis that they come from the same overall population. If they can be said to come from the same population, then we can argue that nonrespondent bias is less of a problem, although this argument will be based on only two data points.

There were 66 categorical questions in the survey. Using SAS PROC FREQ/CHISQ to perform Chi tests on responses to these questions with a dummy variable indicating which mailing ( 1 for respondents who returned the first mailing, and 2 for those who did not respond until the second mailing) indicates that in 13 of the 66 cases can the null hypothesis that the two populations are the same be rejected at the $5 \%$ level. Based on the failure to reject the null in 53 of the 66 tests, nonrespondent bias does not appear to be a problem with this study.

The selection of survey respondents was dependent on the accuracy of the Municipal League's database of community forestry officials. The league attempts to keep current for all incorporated communities in the state but does not include smaller, unincorporated villages. Therefore, we will not try to extend our results to include these smaller communities. In addition, especially in communities that employ no specific community forestry official, we have no way of knowing which official (the mayor, a clerk, etc.) filled in the survey.

\section{Budget and Responsibility for Tree Care}

Most communities continue to rely on general revenues to fund tree care activities. Dollars received through the general revenue stream are vulnerable to reassignment to other priorities in lean budget years. Some communities have found quite creative ways to fund their tree programs. Many respondents marked "other" in response to the query on funding sources and identified partnerships with utility providers (phone and electric), donations, gaming revenue, local volunteer groups, and developers as sources of funding. The challenge for communities is to recognize the value of their community forest as well as the need to fund community forestry activities and develop a stable, diverse revenue stream. Information on creative funding strategies should be a key message of any statewide community forestry program.

The number of communities funding tree programs using sales tax dollars can be expected to rise as communities explore a unique opportunity in Missouri called the Local Parks and Stormwater Tax. This tax, which is subject to local referendum, allows each community to levy a sales tax of up to one-half cent for park and stormwater improvements. To date, the average passage rate of such referenda is 75\% (Ostlund, D., executive director of the Missouri Parks and Recreation Association, personnel communication).

The lack of staffing and budget described by this survey forces communities to be reactive in the management of their community forests. When a tree creates a problem (falls on the road, obscures a view, etc.), the community fixes it. No attempt can be made to be proactive in the elimination of hazards. This approach does not ensure the safety of a community's residents and may in fact put the community at great risk for loss in a lawsuit. A person experiencing damage or loss would simply need to argue negligence by the community. Without a full-time person in place, a focused and methodical approach to tree care and the elimination of hazards is not possible. Because the majority of people who are asked to do tree work have little or no background in tree care, there is a need for state agencies charged with aiding community forestry officials to provide training on basic topics such as hazard tree identification, how to plant, and how to prune, especially in smaller communities.

The most common department charged with tree care, the "maintenance department," is a catch-all category. This same department could also be charged with the care of city sanitation, the city pool, the library, the city cemetery, and other public buildings. Trees are just another component in that mix. It is interesting to note that not all parks and recreation or public works departments are charged with tree care, despite the fact that trees are an integral part of a park system and that road projects have a tremendous impact on street trees. Based on the amount of time dedicated to tree care, trees are not perceived to have similar value and thus are a lower priority despite the fact that trees are a permanent part of a community's infrastructure. The ideal would be for all parks and recreation or public works departments to acknowledge and accept responsibility for tree care and maintenance.

State agencies should bear these findings in mind and make no assumptions where the responsibility for tree care and maintenance lies in a community. Requests for assistance 
often come from multiple departments within a community, making it difficult to deliver targeted and coordinated assistance.

\section{Ordinance and Written Tree Management Plan}

The low numbers of communities with written tree management plans again highlights the reactive nature of most communities to the management of their tree infrastructure. Few communities make an effort to capitalize on the many benefits trees provide or to work proactively to minimize tree loss during development, hazards, and future storm damage. But $51 \%$ of communities with a "comprehensive tree ordinance that defines tree preservation requirement during development" are outside of Missouri's seven fastest-growing counties and the St. Louis metropolitan area. This finding shows a surprisingly proactive approach in "out-state" areas to address the pervasive challenges of growth and development.

The low number of communities with an ordinance and/or a written tree management plan points to the need for greater publicity of the value of trees and the value of planning for proper care. To achieve The National Arbor Day Foundation's Tree City USA certification, a community must meet several requirements including adoption of a comprehensive tree ordinance and development of a written annual work plan. As of 2003, there were 59 Tree Cities in Missouri (about 10\% of the eligible set of 602 communities), while in 1993 there were 21 (Gartner, J., community forestry programs supervisor, Missouri Department of Conservation, personal communication). The Tree City USA communities are more likely than noncertified communities to have tree ordinances and written management plans. Fifty-eight percent of the communities that have a public tree ordinance and $41 \%$ of the communities that have a development tree ordinance were certified Tree City USA communities in 2001. In addition $77 \%$ of the communities with a written tree management plan were Tree City USA communities in 2001 (Gartner, J., community forestry programs supervisor, Missouri Department of Conservation, personal communication). Communities that participate in the Tree City USA program are thus more proactive in managing their trees, perhaps leading to more sustainable management of their community forest. Greater publicity of the benefits of the Tree City USA program may help move communities to action. Such publicity is needed within municipal government and to community residents.

Tree City USA does not, however, require that communities address tree loss during development. Tree loss during development is an emerging issue and one on which state agencies have already focused a significant amount of attention and personnel. Survey results suggest that attention should continue to be focused on innovative methods of development that preserve greenspace, with a concerted effort focused on communities less than 5,000 in population.

\section{Programs Used for Tree Projects in Communities}

The lack of a full-time person with the time and interest to pursue grant opportunities may be a reason smaller communities do not participate in state-funded community forest programs. Further research is needed to identify other obstacles communities with less than 5,000 people must overcome in order to participate in such programs. There is a strong positive correlation between communities willing to budget for tree care activities and their participation in state cost-share programs (significant at over the 99\% level). The survey does not account for participation in cost-share programs by schools and school districts that are often the hub of a smaller community. An analysis of the successful applicants in the Branch Out Missouri tree planting costshare program shows a substantial amount of participation by schools and/or school districts (Gartner, J., community forestry programs supervisor, Missouri Department of Conservation, personal communication).

The strong correlation between the existence of a public tree ordinance and the community's participation in one of the cost-share programs may be a function of the funding structure of the state's cost-share programs. A bonus costshare percentage has been available since the mid-1990s for communities that are certified as a Tree City USA. Certification requires that the community have passed a comprehensive public tree care ordinance.

There are differing levels of participation (Table 5) in the community forest programs between suburbs of Kansas City and suburbs of St. Louis, the two major urban centers of Missouri. There are more than 90 municipalities crowded into the St. Louis metropolitan area. Kansas City is at the other extreme, with a huge land area within the city and a much smaller number (under 30) of suburban communities. The overall population of the St. Louis metropolitan area is nearly twice that of the Kansas City metropolitan area (2.6 million to 1.7 million), but the 2000 census shows similar incomes, education levels, and racial mixes (United States Census Bureau 2003).

\section{Tree Condition and Maintenance}

A lack of technical training and/or education in hazard tree identification among those charged with tree care (i.e., the respondents and their employees) could be the source of the discrepancy between the perceived problem of hazard trees (low) and the documented problem of hazard trees in Missouri (Gartner et al. 2002). Without technical training, it is doubtful that a person could reliably identify hazard trees and make wise choices about trees that present a danger to the public.

Interest in tree pruning is fairly strong, with $60 \%$ of communities ranking it somewhat to very important. The lack of education and experience in working with trees make it unlikely that trees are being pruned to the national 
standard for tree pruning as outlined in the American National Standards Institute's A300 standard practices for woody plant maintenance (1995).

The interest in hazardous trees and tree pruning indicates an interest in public safety and minimizing the community's liability. This interest may be a useful avenue for selling communities on proactive forest management.

The survey found relatively little interest or concern over topped trees. This finding, combined with the fact that only $12 \%$ of trees surveyed in the 1999 re-inventory of street trees were topped, is encouraging (Gartner et al. 2002). Topping, which is common on private property, is not a concern for municipalities. Anti-tree topping educational efforts therefore should focus on home owners, not municipalities.

The level of interest in tree planting, watering, development of a public tree ordinance, and inventory varied widely along the response scale, from "very important" to "not important." This finding may reflect the attitude that because these activities are not required to ensure safety, communities don't see the value of investing money and effort.

The survey found that $71 \%$ of respondents thought that their community's trees were in good condition. This finding contrasts with previous findings from field surveys that only $36 \%$ of public trees were in good to excellent condition (Gartner et al. 2002).

\section{CONCLUSIONS AND RECOMMENDATIONS}

One of the main goals of the survey of community forestry officials was to provide useful recommendations to the state agencies that are charged with helping the community forestry officials with their work. The results of this survey across Missouri allow us to characterize a "typical" Missouri community, to contrast that community with an "ideal" community, and to suggest steps that state agencies can take to move communities toward the latter category.

\section{Characteristics of a Typical Missouri Community}

Most communities

- are reactive in caring for their community forest, with the majority budgeting no dollars for tree care activities

- do not have a full-time person employed to care for publicly owned trees and are unlikely to have even one person who deals with trees occasionally

- do not employ anyone with a B.S. in forestry, horticulture, or a related subject

- do not have a public tree ordinance or a written community forest management plan

- fund or budget tree activities from general revenue

- may locate tree care responsibilities in many different departments

In addition, St. Louis suburban communities seem to be utilizing cost-share programs more than communities in the suburbs of Kansas City.
Most community officials charged with tree care and maintenance

- do not feel that they have sufficient resources to adequately mange and maintain publicly owned trees

- have an interest in minimizing tree loss during construction, but their communities do not have a tree protection ordinance

- feel that their community does not have enough publicly owned trees but do not feel that tree planting is very important

- feel that pruning and removing hazard trees is important

\section{Characteristics of an Ideal Missouri Community}

The National Arbor Day Foundation's Tree City USA

(National Arbor Day Foundation 2003) program outlines four basic elements of a community forestry program to qualify for certification. Those four elements are a good tool to use in assessing a community's forestry program. An ideal community would

- have a tree board or department—someone legally responsible for care of public trees designated by ordinance

- have a tree care ordinance that determines public tree care policies for planting, maintenance and removals; the ordinance also designates the board or department responsible for writing and implementing an annual community forestry work plan

- annually spend at least $\$ 2$ per capita for tree management

- have an annual public education program or event

The survey results show that most small Missouri communities do not have a tree board or department, do not have a public tree care ordinance, and do not budget the desired amount for tree management. Very few seem to have a public education program or event (apart from those provided by MDC's Community Forestry Program). Like Schroeder et al. (2003), this survey found that small communities may benefit from aid on basic tree management. Like Elmendorf et al. (2003), this survey also reinforces the need for a clear communication of these ideas. The survey and analysis leads to the following recommendations:

- Because most communities do not currently hire anyone to work directly with trees, and their budget for trees is often zero, it may be necessary to begin work by meeting with the decision makers in a community (i.e., mayor, city administrator) to stress the importance of personnel and budgets.

- The responsibility for tree care in a given community could be in any number of departments. To deliver targeted and coordinated assistance, state agencies working with communities will need to ask questions to be sure to get to the person who really needs the training/information. 
- Information on how to diversify funding and secure more stable sources of income will prove valuable when meeting with community leaders. A community forestry fact sheet that includes advice on these issues could be developed.

- Most communities lack basic information on tree planting, pruning, hazard tree identification, etc. State agencies and other cooperators should make a concerted effort to provide training of this nature.

- Small communities with adequate budgets may benefit by contracting with consulting urban foresters. This service is not yet widespread in Missouri, both due to lack of resources and knowledge on the part of communities, and to a lack of consulting urban foresters. At least one small community (Lake St. Louis) has tried this approach with some success (Gartner, J., community forestry programs supervisor, Missouri Department of Conservation, personal communication).

- State agencies should form or strengthen partnerships with nongovernmental organizations, such as municipal leagues, to assist with distribution of information on creative funding mechanisms.

- State agencies should continue to make cost-share dollars available to communities to fund community forestry activities, with an emphasis on increasing participation among smaller communities.

- Emphasis on pruning and hazard tree removal may be a way to engage nontraditional communities.

- Interest in tree preservation during development is high in most communities. Efforts to provide information on development principles that preserve or maximize greenspace and conserve watersheds should be enhanced.

\section{LITERATURE CITED}

Akbari, H. 2002. Shade trees reduce building energy use and $\mathrm{CO}_{2}$ emissions from power plants. Environ. Pollut. 116:S119-S126.

Allen, L. 1996. An Analysis of Missouri's Urban Forestry Programs. Master's Thesis. University of Missouri, Columbia. 169 pp.

American National Standards Institute. 1995. American National Standard for Tree Care Operations-Tree, Shrub and Other Woody Plant Maintenance Standard Practice. American National Standards. Institute, New York, NY. 9 pp.

Baker, F. 1993. Monitoring the urban forest_Case studies and evaluations. Environ. Monitor. Assess. 26(2-3):153-163.

Council of Tree $\&$ Landscape Appraisers. 1992. Guide for Plant Appraisal (8th Ed.) International Society of Arboriculture, Champaign, IL. 41 pp.
Dillman, D.A. 2000. Mail and Internet Surveys: The Tailored Design Method. John Wiley \& Sons, New York, NY. 400 pp.

Dwyer, J., E. McPherson, H. Schroeder, and R. Rowntree. 1992. Assessing the benefits and costs of the urban forest. J. Arboric. 18(5):227-234.

Dwyer, J., H. Schroeder, and P. Gobster. 1994. the deep significance of urban trees and forests. In Platt, R., R. Rowntree, and P. Muiick (Eds.). The Ecological City: Preserving and Restoring Urban Biodiversity. University of Massachusetts Press, Amherst, MA.

Elmendorf, W.F., V.J. Cotrone, and J.T. Mullen. 2003. Trends in urban forestry practices, programs and sustainability: Contrasting a Pennsylvania, U.S. study. J. Arboric. 29(4): 237-247.

Gartner, J., T. Treiman, and T. Frevert. 2002. Missouri Urban Forest-A Ten-Year Look. J. Arboric. 28(2):76-83.

Johnston, M., and B. Rushton. 1999. A Survey of Urban Forestry in Britain. University of Ulster, Coleraine, Northern Ireland. 60 pp.

Missouri Department of Conservation. 2003. Tree Resource Improvement and Maintenance Program II: Cost-Share Program. www.mdc.missouri.gov/documents/forest/ TRIM.pdf.

Missouri Secretary of State. 2003. 2000 Population. www.sos.mo.gov/library/reference/census/ cities2000.pdf.

National Arbor Day Foundation. 2003. The Four Standards of a Tree City USA. www.arborday.org/programs/ TreeCityStandards.html.

Nowak D.J., M. Noble, S. Sisinni, and J. Dwyer. 2001. People and Trees-Assessing the US urban forest resource. J. For. 99(3):37-42.

Rocca, J.P. 1992. Survey Shows need for city trees. Mo. Munic. Rev. 57(4):20-21.

Schroeder, H.W., T.L. Green, and T.J. Howe. 2003. Community tree programs in Illinois, U.S.: A statewide survey and assessment. J. Arboric. 29(4):218-224.

Thompson, R., and J. Ahern. 2000. The State of Urban and Community Forestry in California. Technical Report No. 9, California Department of Forestry and Fire Protection, Urban Forestry Program, San Luis Obispo, CA. 48 pp.

Treiman, T., and J. Gartner. 2003. Urban Forestry in Missouri Communities: Attitudes and Knowledge of Local Officials. An Attitude Survey and Analysis for the Missouri Department of Conservation. Missouri Department of Conservation, Jefferson City, MO. 45 pp.

United States Census Bureau. 2003. American FactFinder. factfinder.census.gov. 


\author{
$1 *$ Natural Resource Economist \\ Resource Science Division \\ Missouri Department of Conservation \\ 1110 S. College Ave. \\ Columbia, MO 65201, U.S.
}

\section{${ }^{2}$ Field Program Supervisor}

Forestry Division

Missouri Department of Conservation

P.O. Box 180

Jefferson City, MO 65102, U.S.

*Corresponding author.

Résumé. Un sondage a été utilisé pour aider à comprendre la connaissance, la motivation et le comportement de ceux qui sont responsables de l'entretien des arbres au sein de 602 communautés du Missouri, U.S. Notre but était de caractériser les agences locales qui étaient responsables de la gestion des arbres urbains, de leur budget et du personnel ainsi que de déterminer quelles étaient les enjeux les plus pressants que les responsables locaux officiels avaient à gérer par rapport aux arbres publics. Cette information est utilisée pour évaluer le Programme communautaire forestier de l'état qui est conçu pour coordonner et faciliter les efforts faits par plusieurs juridictions et entités qui possèdent et affectent les forêts communautaires. Les découvertes au sein de cette enquête indiquent que la plupart des communautés manquent d'informations de base en regard de l'entretien des arbres et n'emploient pas une personne spécifique pour l'entretien des arbres publics. La responsabilité de l'entretien des arbres peut se retrouver dans nombre de départements, ou encore dans aucun. Les agences qui œuvrent avec les communautés vont avoir besoin de cibler la formation de base et l'information. Linformation sur le comment diversifier les sources d'argent et sécuriser des sources plus stables de revenus va s'avérer utile du fait que plusieurs communautés n'allouent aucun dollar pour l'entretien des arbres. Le partage des coûts devrait aussi être ciblé avec une emphase sur l'accroissement de la participation au sein des petites communautés. Lintérêt envers la préservation des arbres est élevé lors des projets de construction dans la plupart des communautés, ce qui met en lumière le besoin de fournir de l'information sur les principes de développement qui préservent ou maximisent les espaces verts.

Zusammenfassung. Es wurde eine Umfrage durchgeführt, um das Wissen, die Motivation und das verhalten der für die Baumpflege Verantwortlichen in 602 Kommunen in Missouri, U.S. besser zu verstehen. Unser Ziel war es, die örtlichen Agenturen zu charakterisieren, die damit beauftragt werden, die Bäume, ihr Budget und den
Personalbedarf zu managen und zu bestimmen, mit welchen Themen die örtlichen Behörden bei der Baumpflege konfrontiert sind. Diese Informationen werden benutzt, um das staatliche Kommunale Forstprogramm zu bewerten, welches dafür entwickelt wurde, die vielen Verordnungen und Gerichtsbarkeiten, die Bäume besitzen und verwalten, zu koordinieren. Die Ergebnisse der Umfrage zeigten, dass den meisten Kommunen grundlegende Informationen über Baumpflege fehlen und dass sie niemanden beschäftigen, der sich hauptberuflich um die Baumpflege kümmert. Die Verantwortung für die Baumpflege kann in jeder (oder keiner) Abteilung liegen. Agenturen, die mit Gemeinden zusammenarbeiten, werden sich auf grundlegende Schulung und Information einstellen müssen. Informationen darüber, wie die bestehenden Budgets diversifiziert werden können, sichere Einkommensquellen geschaffen werden, werden sehr wertvoll, da die meisten Gemeinden bislang keinen Etat für Baumpflege haben. Kostenteilungsmodelle sollten mit einer Betonung auf die wachsende Anzahl kleinerer Gemeinden entwickelt werden. Interesse an der Baumerhaltung während der Entwicklung ist in den meisten Kommunen sehr hoch und unterstreicht das Bedürfnis, Informationen über die Entwicklungsprinzipien zu liefern, die Grünflächen erhalten oder maximieren wollen.

Resumen. Se llevó a cabo una consulta para ayudar a entender el conocimiento, motivación y comportamiento de los responsables para el cuidado de los árboles en 602 comunidades de Missouri, U.S. El objetivo fue caracterizar las agencias locales encargadas del manejo de los árboles urbanos, sus presupuestos y personal, y determinar cuales aspectos responden por el manejo de las políticas hacia los propietarios de los árboles. Esta información es usada para evaluar el Programa Forestal Estatal, el cual es designado para coordinar y facilitar los esfuerzos hechos por muchas jurisdicciones y entidades que poseen un afecto hacia los bosques comunales. Los resultados indican que la mayoría de las comunidades carecen de información básica sobre el cuidado del árbol y no emplean a nadie específicamente para cuidar los árboles de la comunidad. La responsabilidad para el cuidado del árbol puede estar en cualquier número de departamentos (o ninguno). Las agencias que trabajan con las comunidades necesitarán apuntar hacia entrenamiento básico e información. La información sobre cómo diversificar los fondos y asegurar fuentes de recursos más estables es valiosa, debido a que los presupuestos de muchas comunidades tienen cero dólares para el cuidado de los árboles. Esto debe hacer énfasis sobre el incremento de la participación entre las comunidades más pequeñas. El interés en la preservación de los árboles durante el desarrollo es alto en la mayoría de las comunidades, subrayando la necesidad de mejorar la información sobre los principios que preservan o maximizan el espacio verde. 